\title{
Current Perspectives on Teaching the Four Skills
}

ELI HINKEL

Seattle University

Seattle, Washington, United States

This article presents an overview of recent developments in second language (L2) teaching and highlights the trends that began in the 1990 s and the 2000 s and are likely to continue to affect instruction in L2 skills at least in the immediate future. Also highlighted are recent developments in instruction as they pertain specifically to the teaching of L2 speaking, listening, reading, and writing. In the past 15 years or so, several crucial factors have combined to affect current perspectives on the teaching of English worldwide: (a) the decline of methods, (b) a growing emphasis on both bottom-up and top-down skills, (c) the creation of new knowledge about English, and (d) integrated and contextualized teaching of multiple language skills. In part because of its comparatively short history as a discipline, TESOL has been and continues to be a dynamic field, one in which new venues and perspectives are still unfolding. The growth of new knowledge about the how and the what of $L 2$ teaching and learning is certain to continue and will probably remain the hallmark of TESOL's disciplinary maturation.

T oday, it is a truism to say that each era in the history of second language (L2) teaching has been marked by expansions of knowledge and pivotal advancements in disciplinary theory and practice. One unfortunate side effect of ongoing disciplinary innovation and a search for the best teaching method is what Richards (2005) referred to as "the theoretical flavor of the month" (n.p.), alluding to recurrently fashionable theories of language learning and use that claim to be based on the findings of current research. However, implicit in a view of the ongoing development of L2 teaching is an expectation that what is current, innovative, and central in L2 pedagogy today is likely to become a stepping-stone in the expansion and refinement of disciplinary knowledge. This overview of the current perspectives in L2 teaching highlights the trends that began in the 1990s and the 2000 s and are likely to continue to affect instruction in L2 skills at least in the immediate future.

In the current dynamic perspectives on foundational L2 skills, four 
overarching themes can be identified: the decline of methods, the significance of both bottom-up and top-down skills in L2 learning, the applications of new knowledge about the English language to L2 pedagogy, and the teaching of integrated and multiple skills in context. The overview begins with these four trends, which are the hallmarks of current pedagogy in all L2 skills. ${ }^{\prime}$ Recent developments in instruction are then highlighted as they pertain specifically to the teaching of L2 speaking, listening, reading, and writing.

\section{FOUR THEMES IN GURRENT L2 PEDAGOGY}

Several crucial factors have combined to shift current perspectives on L2 teaching: (a) the decline of methods, (b) a growing emphasis on both bottom-up and top-down skills, (c) new knowledge about English, and (d) integrated and multiple skills taught in context. These factors have had a profound influence on classroom instruction and curriculum development in practically all L2 skills and across learner proficiency levels.

\section{Decline of Methods}

Recognition of the essential roles of the teacher and the learner and of the need for situationally relevant language pedagogy has brought about the decline of methods, with their specific philosophies and prescribed sets of classroom procedures.

As early as the mid-1980s, a small number of researchers and methodologists began to voice growing apprehension about the worldwide applicability of any particular method to the enormous diversity of learners and learning needs. Since that time, many L2 professionals have come to see specific teaching methods as overly prescriptive and inapplicable in divergent learning contexts (e.g., Brown, 2001; Kumaravadivelu, 2003, 2005). For example, although communicative skills can occupy a high priority for ESL students who need to interact in their L2, for EFL learners, communicating in English may have a reduced value relative to preparing for entrance exams or tests for securing employment. The past two decades have seen a shift in the responsibility for curricular and

\footnotetext{
1 The 25th anniversary issues of TESOL Quatterly reflected the general trend of treating the foundational language skills separately. A broad overview such as this one may well represent an innovation in itself to evince the maturation of L2 teaching as a discipline as well the influential expansion of integrated instructional models (discussed in the section Integrated and Multiple Skills Taught in Context).
} 
instructional decisions from the prevailing teaching methods to classroom teachers and learners, who are best suited to implement appropriate, relevant, and effective instruction (e.g., Breen \& Littlejohn, 2000). For instance, Larsen-Freeman (2000) recommends that teachers practice "principled eclecticism" and create their own teaching methods "by blending aspects of others in a principled manner" (p. 183).

The centrality of key learner variables, such as learning needs and goals, as well as cognitive processing and resources has been widely recognized in research and pedagogy (e.g., see Bialystok, 2002; Fotos, 2001). Investigations into the social, cultural, economic, and political contexts of L2 learning have provided much insight into populations of learners and their specific learning goals. While some may need to speak and write in L2 academic and professional settings, others set out to develop L2 conversational or reading skills for different purposes. Such fundamental factors as who given L2 learners are, why and where these individuals undertake to learn an L2, and what their available resources are (e.g., time, cognitive, financial) should and often do determine how particular L2 skills are taught and learned (e.g., Breen, 2001; Breen \& Littlejohn, 2000).

\section{Bottom-Up and Top-Down Skills}

Based on recent research on the role of cognition in $L 2$ learning, $L 2$ pedagogy in practically all skills has come to recognize the importance of both accuracy and fluency and both bottom-up and top-down language skills (discussed in the sections on teaching speaking, listening, reading, and uriting).

In the late 1980s and early 1990s, a number of studies were carried out to determine whether exposure to and communicative interaction in the L2 enables learners to attain L2 speaking facilities that address fluency and accuracy in language production (e.g., Lightbown \& Spada, 1990; Schmidt, 1993; Swain, 1991). Research findings demonstrate that, without explicit and form-focused instruction, extensive exposure to meaning-based input does not lead to the development of syntactic and lexical accuracy in an L2. Currently, in the teaching of the four skills, curricula and instruction strive to achieve a balance between the linguistic and the schematic aspects of learner language development. At present, practically all teacher education textbooks on the essentials of language instruction include material on how to address both bottom-up and topdown abilities (e.g., Adger, Snow, \& Christian, 2002; Brown, 2001; Carter \& Nunan, 2001; Celce-Murcia, 2001; Larsen-Freeman, 2000; Nunan, 1999, 2003). 


\section{New Knowledge About English}

The analyses of large spoken and written English language corpora have allowed much insight in to how native speakers of English use language features in real life and across various dialects. New empirical knowledge about the English language has had an important influence on curricula and content in L2 pedagogy.

The findings of corpus analyses have identified variations of language features in spoken or written registers and across several types of genres, such as academic or journalistic prose, as well as formal or conversational speech. These analyses of real-life language in use have delved into, for example, the frequencies and patterns of syntactic, morphological, lexical, pragmatic, or discoursal features that tend to occur in particular types of text (see Conrad, 2005, for a detailed overview).

Applications of corpus analyses findings to L2 teaching, however, have not been without controversy. Some language corpora are specifically created and analyzed with the intent to benefit L2 instruction and improve the efficiency of learning. For example, studies of vocabulary frequencies and ranges in introductory universicy courses across such diverse disciplines as economics, history, and biology are very useful in teaching academically bound or professional L2 learners (e.g., Hazenberg \& Hulstijn, 1996; Nation, 1990, 2001). Other analyses of English language corpora are primarily focused on the empirical study of language to obtain detailed descriptions of its properties that can be applied to the refinement of language theories. Some prominent experts in L.2 teaching and linguistics have questioned the value of applying corpus findings to L2 teaching. For instance, according to Widdowson (1990, 2000, 2003) and Cook (1997, 1998), learners in EFL settings, who in effect have few opportunities to interact with native speakers of English, do not need to be particularly concerned with the frequencies of linguistic features in native speaker corpora. These authors also argue that, in many cases, corpus findings are too culturebound and narrowly specific to a particular variety of English to be useful for learners who have no access to that culture or variety. Furthermore, the issues of difficulty, learnability, usefulness, relevance, and pedagogical sequencing have to be taken into account in corpus-based L2 teaching and instructional materials (e.g., Aston, 1995; for a discussion, see also Conrad, 2005). Many L2 methodologists believe, however, that corpus findings can make L2 teaching far more effective and efficient by identifying the language features that learners must know to achieve their learning goals (e.g., Byrd, 2005; Byrd \& Reid, 1998; Conrad, 2000). 


\section{Integrated and Multiple Skills Taught in Context}

In an age of globalization, pragmatic objectives of language leaming place an increased value on integrated and dynamic multiskill instructional models with a focus on meaningful communication and the development of leamers' communicative competence.

In many locations around the world, learning English has the objective of learners' gaining access to technical, educational, or professional opportunities (Canagarajah, 2002, 2005). Commonly accepted perspectives on language teaching and learning recognize that, in meaningful communication, people employ incremental language skills not in isolation but in tandem. For example, to engage in a conversation, one needs to be able speak and comprehend at the same time. To make language learning as realistic as possible, integrated instruction has to address a range of $\mathrm{L} 2$ skills simultaneously, all of which are requisite in communication. For instance, teaching reading can be easily tied to instruction on writing and vocabulary, and oral skills readily lend themselves to teaching pronunciation, listening, and cross-cultural pragmatics (Hinkel, 2001; Lazaraton, 2001; McCarthy \& O'Keeffe, 2004).

Integrated and multiskill instruction usually follows the principles of the communicative approach, with various pedagogical emphases, goals, instructional materials, activities, and procedures playing a central role in promoting communicative language use. At present, the models for integrated teaching with a communicative focus include an extensive array of curricula and types of instructional models, such as content based (including theme based), task based, text based (also called genre based), discourse based, project based, problem based, literature based, literacy based, community based, competency based, or standards based (and this is not a complete list by any measure). In fact, Richards and Rodgers (2001) note that, as long as instruction engages learners in meaningful communication and enables them to attain the curricular objectives, the range of models and teaching materials compatible with integrated language teaching is "unlimited" (p. 165).

It is safe to say, however, that few movements in foreign language (FL) and L2 teaching take place without contest, and integrated language instruction is certainly no exception. Currently, task-based and contentbased instruction are probably among the most widely adopted integrated models. However, some leading specialists in L2 teaching and applied linguistics have maintained that the superiority of, for example, task-based instruction over traditional teaching has not been demonstrated empirically and that to date research has had little to say about its effectiveness (e.g., Richards \& Rodgers, 2001; Seedhouse, 1999; Swan, 2005; Widdowson, 1990, 1993, 2003). Critics also contend that in many 
ESL and EFL situations worldwide, the implementation of content-based and task-based instruction may be simply inappropriate and impractical (e.g., Swan, 2005; Ur, 1996). For example, FL or L2 proficiency cannot be developed when learning is limited to 1-3 hours of classroom instruction and input (e.g., Lightbown, 2000; Lightbown \& Spada, 1990). Additionally, when instruction in content areas, such as science or math, is carried out in English in EFL settings, teachers often find it difficult to maintain expertise in both English and the subject matter, and learners who need to prepare for examinations often concentrate only on school subjects without much interest in learning the language. In task-based, multiskill instruction, with its focus on the development of language fluency, issues of content or linguistic accuracy are of secondary importance, thus limiting the usefulness of the task-based model for schooling and academic preparation (see Richards \& Rodgers, 2001; Widdowson, 1990, 2003). Based on their experience, however, many L.2 teachers and curriculum designers believe that integrated FL/L2 instruction can increase learners' opportunities for L2 purposeful communication, interaction, real-life language use, and diverse types of contextualized discourse and linguistic features, all of which have the goal of developing students' language proficiency and skills (for detailed discussion, see, e.g., Ellis, 2003; Fotos, 2001, 2002; Snow, 2005).

The remainder of this article delves into a more detailed overview of the prevailing currents in the teaching of the L2 foundational skills: speaking, listening, reading, and writing. This traditional division has the sole purpose of easing the reader's navigation through the article's contents, and some generally accepted ways to integrate the teaching of L2 skills will be addressed as a matter of course.

\section{TEACHING SPEAKING SKILLS}

The complexity of learning to speak in another language is reflected in the range and type of subskills that are entailed in L2 oral production. Learners must simultaneously attend to content, morphosyntax and lexis, discourse and information structuring, and the sound system and prosody, as well as appropriate register and pragmalinguistic features (Tarone, 2005). In an interaction that typically involves speaking and comprehending at the same time, L2 speakers need to self-monitor so that they can identify and correct production problems at the fast pace of a real conversational exchange. Research on the characteristics and development of L2 oral skills has shown conclusively that communicating in an L2 is a cognitively demanding undertaking, not to mention that the success of an interaction often depends on production quality (e.g., McCarthy \& O'Keeffe, 2004). Thus, speaking in an L2 requires fluency, 
accuracy, and a sufficient lexicogrammatical repertoire for meaningful communication to take place.

In the 1990s, many researchers concluded that exposure to and communicative interaction in an L2 enables learners to attain L2 speaking fluency. However, the extent of fluency development was not matched by learners' syntactic and lexical accuracy in oral production (e.g., Lightbown \& Spada, 1990; Schmidt, 1993; Swain, 1991). These and many other studies demonstrated that although, for example, immersion learners can speak fluently and with ease, their speech contained numerous grammatical, lexical, and pragmalinguistic errors.

Within communicative and task-based approaches to teaching, various methodological modifications in L2 speaking pedagogy have been proposed that permit an integration of fluency and accuracy foci (e.g., Fotos, 2002). For instance, according to Ellis (2003), the task-based teaching of L2 speaking skills has built-in opportunities for online planning that result in more accurate and complex uses of language. Ellis explains that carefully designed tasks can foster the development of various aspects of $\mathrm{L} 2$ oral production: Narratives and descriptions can be effective in fluency-focused teaching, and, for example, debates and problem-solving tasks can promote increased grammatical and lexical complexity in learner language use. Another advantage of using tasks in L2 oral instruction is that rehearsal (or task repetition) affords learners an opportunity to accommodate the competing cognitive demands of fluency, accuracy, and linguistic complexity. For example, advance planning and rehearsals of content and formulation, that is, what to say and how to say it, lead to substantial improvements in the amount of spoken discourse and in grammatical, lexical, and articulatory accuracy. In content-based and task-based instruction, contextualized uses of specific grammar structures and vocabulary can be emphasized to connect the subject matter and language learning activities (for a thorough overview, see Snow, 2005).

\section{Speaking Integrated With Other Language Skills}

\section{Speaking and Pronunciation}

The rapid pace of the internationalization of English has led to changing perspectives on the teaching of pronunciation. In general terms, as Tarone (2005) points out, the goal of pronunciation teaching has shifted from targeting a nativelike accent to targeting intelligibility, that is, the degree to which the listener understands the speaker's utterance. In an age when English has become a primary medium for international communication, most cross-cultural interactions take place 
between nonnative speakers of English rather than between native and nonnative speakers (e.g., Canagarajah, 2005; Jenkins, 2000, and this issue). Thus, today, L2 pronunciation pedagogy has the objective of helping learners achieve overall intelligibility rather than drastic accent modification (e.g., McKay, 2002). To this end, teaching has to address the issues of segmental clarity (e.g., the articulation of specific sounds), word stress and prosody, and the length and the timing of pauses. The current approach to teaching pronunciation is generally based on three principled criteria: (a) Pronunciation and intonation are taught in context and in conjunction with speaking skills, (b) instruction in pronunciation serves broader communicative purposes, and (c) the teaching of pronunciation and intonation is based on realistic rather than idealistic language models (e.g., Chun, 2002).

\section{Speaking and Pragmalingistic Skills}

As an additional outcome of increased global mobility and the internationalization of English, instruction in L2 speaking skills has been placing a greater emphasis on the sociocultural features of communication and oral production. The 1990s saw a remarkable growth of publications associated with the importance of L2 sociocultural and pragmalinguistic competence. For this reason, current oral pedagogy has the objective of enabling nonnative speakers to communicate effectively and to negotiate cross-cultural interactional norms successfully (Kasper \& Roever, 2005; McKay, 2002). The teaching of L2 sociopragmatic skills elucidates the issues of power in communication, such as the impact of social status, social distance, and linguistic register on L2 speech.

At present, pedagogy on L2 sociopragmatic norms of speaking typically incorporates effective communication strategies; discourse organization and structuring; conversational routines (e.g., small talk); conversational formulae (e.g., forms of address); and speech acts, such as requests, refusals, compliments, or clarification questions (e.g., McKay, 2002; Yule \& Tarone, 1997). According to Kasper's (2001) overview of several empirical studies on teaching L2 pragmatics, explicit teaching and direct explanations of the $\mathrm{L} 2$ form-function connections represent a highly productive means of helping learners improve their L2 sociopragmatic skills. For example, turn the radio down and could you please turn the radio down have the same function (request) but different pragmalinguistic forms, and, depending on the context, one is likely to be more effective than the other. Implicit instruction in various communication tactics and appropriate language uses (i.e., when pragmatic features are pracliced in context without descriptions and explanations) 
can be far less effective than explicit explanations and teaching (see Kasper \& Roever, 2005, for further discussion).

\section{Linguistic Features of Spoken Register}

Analyses of English language corpora, as noted earlier, have been able to identify the specific lexical and grammatical features that distinguish, for example, oral and written discourse, or casual conversations and formal speech. Noticing and analyzing divergent linguistic features frequently encountered in, for example, conversations or university lectures are useful in teaching both speaking and listening for interactional, academic, or vocational purposes (see also Celce-Murcia \& Olshtain, 2000; Master, 2005). In fact, curricula that attend to the distinctions between conversational and formal oral production can prepare learners for real-life communication in EFL and ESL environments alike (I_azaraton, 2001).

\section{TEACHING LISTENING}

During the 1970s, listening pedagogy largely emphasized the development of learners' abilities to identify words, sentence boundaries, contractions, individual sounds, and sound combinations, that is, bottom-up linguistic processing. The 1980 s saw a shift from the view of L2 listening as predominantly linguistic to a schema-based view, and listening pedagogy moved away from its focus on the linguistic aspects of comprehension to the activation of learners' top-down knowledge. In top-down processing, aural comprehension hinges on listeners' abilities to activate their knowledge-based schemata, such as cultural constructs, topic familiarity, discourse clues, and pragmatic conventions (e.g., CelceMurcia, 1995; Mendelsohn, 1994; Rost \& Ross, 1991). In the practice of teaching L2 listening, however, neither approach-a focus on bottom-up or top-down processing-proved to be a resounding success: Learners who rely on linguistic processing often fail to activate higher order L2 schemata, and those who correctly apply schema-based knowledge tend to neglect the linguistic input (e.g., Tsui \& Fullilove, 1998; Vandergrift, 2004).

Advances in the studies of spoken corpora and conversation analysis have illuminated the complexity of oral discourse and language. The findings of these analyses have made it evident that, in many cases, employing authentic language in listening instruction can be of limited benefit because of a variety of constraints, such as the fast pace of speech, specific characteristics of spoken grammar and lexicon (e.g., incomplete 
sentences and ellipses, as in he did what?), cultural references and schemata, and dialectal colloquial expressions. Although L2 pedagogy continues to underscore the value of authentic teaching materials, the research on the effectiveness of $\mathrm{L} 2$ listening instruction broadly recommends learner training in metacognitive strategies to facilitate the development of $\mathrm{L} 2$ aural abilities.

In L2 listening pedagogy, two complementary approaches reflect current perspectives on more effective learning. One emphasizes the integrated teaching of listening for communication and in conjunction with other L2 skills, such as speaking, sociopragmatics, grammar, and vocabulary. The other moves to the foreground the learner's use of metacognitive and cognitive strategies to bolster the learning process (Mendelsohn, 1994; Rost, 2005; Vandergrift, 1999, 2004).

\section{Listening Integrated With Other Language Skills}

\section{Listening, Discourse, and Linguistic Skills}

Generally speaking, a variety of techniques in L2 listening instruction have withstood the test of time and are largely recognized as essential, for example, prelistening, making predictions, listening for the gist or the main idea, listening intensively, and making inferences. These teaching strategies can be useful in a broad range of teaching contexts and can meet diverse learning needs. For instance, prelistening activities can be employed in teaching learners to notice the cultural schema and to raise their awareness of the effect of culture on discourse organization, information structuring, and pragmatics (see, e.g., Rost, 2005; Vandergrift, 2004). In addition, learning to listen to conversations provides a fruitful venue for focusing on morphosyntax, lexical parsing, and phonological variables, thus adding new dimensions to the teaching of grammar and vocabulary. Analyses of L2 conversations can similarly emphasize L2 sociocultural norms and pragmatics to expand learners' repertoire of common speech acts and discourse structuring. As has been mentioned, the teaching of pronunciation skills is also ubiquitously integrated with both speaking and listening instruction.

The linguistic and schema-driven staples of teaching listening have found applications in current integrated approaches, such as task-based or content-based instruction (see Snow, 2005, for overviews). The design of listening practice can incorporate a number of features that make the development of L2 listening abilities relevant and realistic. Listen-and-do tasks, for instance, represent a flexible source of listening input for beginning or intermediate learners. According to Ellis (2003), the 
content of tasks can be easily controlled in regard to their linguistic and schematic variables, such as frequent occurrences of target syntactic and lexical structures in the context of a meaning-focused task (also referred to as enriched input), such as grammar constructions, words and phrases, or conversational expressions. Academic listening tasks and note-taking are an age-old technique for teaching more advanced learners. Taped (or live) listening selections, such as academic lectures, can be designed to concentrate on specific topics and contents with directed grammar and vocabulary loads, and cultural and discourse schemata, integrated with reading, writing, and speaking practice.

\section{Teaching Listening and Teaching Strategies}

In the 1990s, in addition to linguistic and schematic considerations in L2 listening, a number of studies identified the difficulties learners experience when coping with comprehension problems and making inferences. Researchers have also been interested in the metacognitive and cognitive strategies of successful L2 listeners (e.g., Rost \& Ross, 1991; Vandergrift, 1999, 2004). The findings of these investigations have led L2 listening experts to advocate the teaching of metacognitive and cognitive strategies specifically for L2 listening comprehension. The most important difference between skills and strategies is that strategies are under learners' conscious control, and listeners can be taught to compensate for incomplete understanding, missed linguistic or schematic input, or misidentified clues (see Rost, 2005, for a discussion).

Thus, current L2 listening pedagogy includes the modeling of metacognitive strategies and strategy training in tandem with teaching L2 listening. A consistent use of metacognitive strategies is more effective in improving learners' L2 listening comprehension than work on listening skills alone (e.g., Vandergrift, 2004). The key metacognitive strategies widely adopted in L2 listening instruction include planning for listening, self-monitoring the comprehension processes, evaluating comprehension, and identifying comprehension difficulties (e.g., see Rost, 2005, for a discussion). Learners at beginning and intermediate levels of proficiency may benefit from instruction that concentrates on bottom-up and top-down listening processes, together with selective strategy training. For more advanced learners, an addition of cognitive strategies, such as discourse organization, inferencing, elaboration, and summation, also represent an effective approach to teaching listening (Rost, 2001; Rost \& Ross, 1991). 


\section{TEACHING L2 READING}

Recent research has shed a great deal of light on the processes and the learning of $L 2$ reading. Similar to L2 listening, L2 reading entails both bottom-up and top-down cognitive processing, and in the 1980s, the prevalent approach to teaching sought to activate learners' L1 reading schemata and prior knowledge to foster the development of L2 reading skills. Over time, however, it has become evident that, despite many years of schooling and exposure to L2 reading and text, not all learners succeed in becoming proficient L2 readers. In his important overview of reading research, Eskey (1988) examines what he called "a strongly topdown bias" (p. 95) in L2 reading pedagogy and neglect of learners' weak linguistic processing skills. Eskey's analysis explains that L2 readers are fundamentally distinct from those who read in their Lls and that essential "knowledge of the language of the text" (p. 96) is required before learners can successfully process the L2 reading schema. The primacy of the bottom-up processing in L2 reading and the need for teaching the language in L2 reading are similarly noted by Paran (1996), Birch (2002), and Koda (2005), who view the top-down reading skills as additive or compensatory once fluent bottom-up processing is achieved.

\section{Reading Integrated With Other Language Skills}

\section{Bottom-Up and Top-Down Skills}

The bottom-up processing of reading involves a broad array of distinct cognitive subskills, such as word recognition, spelling and phonological processing, morphosyntactic parsing, and lexical recognition and access (e.g., Eskey, 2005). The reader needs to gather visual information from the written text (e.g., letters and words), identify the meanings of words, and then move forward to the processing of the structure and the meaning of larger syntactic units, such as phrases or sentences. A number of studies, such as those by Koda (1999), Chikamatsu (1996), and Shimron and Savon (1994), have shown that visual processing of words and letters represents a cognitively complex task. These and other researchers found that readers whose L1 orthographies (e.g., Chinese, Japanese, or Hebrew) are markedly distinct from the L2 orthography may be slowed down in their reading progress by the need to attain fluent $L 2$ word recognition before they can acquire text-processing skills. Furthermore, positive L1-to-L2 transfer of reading skills does not occur when the writing systems in the two languages are fundamentally different (e.g., Birch, 2002; Koda, 1999, 2005). On the other hand, L2 
readers' word-processing skills develop significantly faster when Ll and L2 orthographies are similar (as in English and Spanish).

The findings of $L 2$ reading research on the key role of bottom-up processing, word recognition fluency, and the recognition of the morphophonemic structure of words and phrases have led to substantive shifts in reading and literacy instruction to young and adult L.2 learners alike. For example, in 1999, the far-reaching National Literacy Strategy in the United Kingdom introduced work on phonics, word recognition, and graphic knowledge prior to sentence and text levels of instruction.

In teacher education, current methodology textbooks reflect the change in the perspectives on teaching $L 2$ reading, literacy, and writing (see also the section Teaching Writing). Such influential publications as those by Celce-Murcia (2001), Carter and Nunan (2001), McKay (1993), Nunan $(1999,2003)$, and Wallace (1992) contain at least a chapter on teaching bottom-up reading skills usually followed by instruction in topdown and strategic reading. For example, Ediger (2001) cautions that L1 reading skills do not readily transfer to an $\mathrm{L} 2$. In the case of young school-age and older learners alike, teachers need to begin with work on the visual appearance of words (e.g., a sight-word approach, p. 157), soundletter relationships (e.g., the look-say approach, p. 157), and the development of word recognition fluency before delving into top-down skills in both reading and writing. Similarly, Wallace (2001) reviews research on fostering the learner's ability to decode words as a prerequisite to reading. Based on the conclusions of various studies, Wallace explains that a strong link exists "between phonemic awareness, the ability to process words automatically and rapidly, and reading achievement" ( $p$. 23). In her practical book for teachers, Birch (2002) advocates teaching $L 2$ reading by beginning with processing letters, then moving forward to the English spelling system, morphophonemics, and vocabulary learning. According to Birch, although both bottom-up and top-down processing skills are necessary to learn to read in an L2, the reading fundamentals must be in place before top-down instruction can benefit learners.

\section{Reading and Vocabulary}

In other venues, the foundations-first perspective on $L 2$ reading pedagogy also extends to today's views on teaching and learning vocabulary. Enormous amounts of research carried out in the past two decades have been devoted to the role of vocabulary in $L 2$ reading as well as to vocabulary learning and acquisition. Although in the 1970s and 1980s the teaching and learning of vocabulary was considered to be largely secondary to the teaching of other L2 skills, at present a great deal more 
is known about the connections between L2 reading and vocabulary knowledge (e.g., Nation, 1990, 2001). For instance, $\mathrm{Hu}$ and Nation (2000) indicate that an L2 reader needs to understand approximately $98 \%$ of the unique words in such texts as short novels or academic materials. In real terms, this represents about 5,000 word families (a family is a base word with its related words and their inflected forms, e.g., child, children, childhood). On the other hand, according to Hazenberg and Hulstijn (1996), the vocabulary range in introductory university textbooks largely overlaps with that in the general corpus of frequent words. Therefore, irrespective of their aspirations to enter universities, L2 learners need to acquire a substantial vocabulary to achieve competencies in practically all L2 skills, such as reading, writing, listening, and speaking (e.g., Coady \& Huckin, 1997). In general terms, a vocabulary of approximately 2,000 words may serve as an essential base needed for daily interaction and speaking, whereas 5,000 base words are typically considered to be a minimal L2 learning goal to comprehend texts intended for a general, nonspecialist audience (Nation, 1990; see also Hulstijn, 2001, for an overview).

The techniques for teaching vocabulary have also been thoroughly examined. Among other prominent publications, Nation's (2001, 2005) work highlights significant trends in productive and efficient vocabulary teaching. In the past two clecades, a vast body of research has established that explicit teaching represents the most effective and efficient means of vocabulary teaching. Researchers have also voiced caution that incidental learning leads to significantly lower rates of vocabulary retention and that a word needs to be encountered 12-20 times to be learned from context (e.g., Coady, 1997). According to Nation (2005) and Hulstijn (2001), research has not supported the contention that meaning-focused use and encounters with new words in context are the best way to learn vocabulary. These authors underscore that the converse approach is probably true, that is, deliberate attention to decontextualized words is far more likely to lead to learning, although new vocabulary can certainly be reinforced in the context of other L2 skills. In general terms, to result in learning, activities with new words, such as reading or listening, have to meet the following conditions: "interest, repetition, deliberate attention, and generative use (the use of a word in a new context)" (Nation, 2005, p. 585). Teaching word families rather than individual words can dramatically increase the rate of learning.

\section{Extensive Reading and Reading Fluency Development}

A pedagogical approach usually referred to as extensive reading (or sustained silent reading) has been very popular among reading teachers 
and methodologists. Extensive reading is based on the principles adopted in $\mathrm{Ll}$ reading and literacy instruction, and, intuitively, it can be appealing because of its emphasis on reading large amounts of material for enjoyment. In fact, Eskey (2005) points out that "the relationship between reading and vocabulary is well documented and reciprocal" (p. 567 ), and the more one reads, the larger his or her language base becomes. The goal of extensive reading is to read relatively quickly and to understand general ideas rather than to focus on the details. It is generally recognized that extensive reading can provide learners with exposure to new and old vocabulary and facilitate the development of reading fluency (e.g., Coady, 1997; Eskey, 2005; Nation, 2001). According to $\mathrm{Hu}$ and Nation (2000), the usefulness of extensive reading is contingent on the density of unknown words, which should not exceed 1 for every 50 words of text. Also, vocabulary should recur at fairly regular intervals to promote retention. For less proficient learners, graded or simplified readers with controlled vocabulary loads may be the optimal choice, even though many teachers dislike graded reading materials. As Nation (2005) mentions, "Without graded readers, reading for a second language learner would be one continuous struggle against an overwhelming vocabulary level" (p. 588).

\section{TEACHING L2 WRITING}

Although in the 1980s much in the teaching of L2 writing was based on L1 writing research, in the past two decades, a number of publications have emerged to address the important differences that exist between learning to write in one's L1 and in one's L2 (e.g., Hinkel, 2002; McKay \& Wong, 1996; Silva, 1993). Based on his synthesis of 72 studies, Silva (1993) concludes that significant differences exist between practically all aspects of Ll and L2 writing. He emphasizes that the learning needs of L2 writers are crucially distinct from those of basic or proficient L1 writers and that L2 writing pedagogy requires special and systematic approaches that take into account the cultural, rhetorical, and linguistic differences between L1 and L2 writers. Similarly, Hinkel's (2002) largescale empirical analysis of $\mathrm{Ll}$ and L2 text showed that even after years of ESL and composition training, L2 writers' text continues to differ significantly from that of novice $\mathrm{Ll}$ writers in regard to most linguistic and rhetorical features. Even advanced and trained L2 writers continue to have a severely limited lexical and syntactic repertoire that enables them to produce only simple text restricted to the most common language features encountered predominantly in conversational discourse (Hinkel, 2003). 


\section{Writing Integrated With Other Language Skills}

\section{Bottom-Up and Top-Down Skills}

As with $\mathrm{L} 2$ reading, $\mathrm{L} 2$ writing pedagogy has begun to pay increasing attention to the integration of bottom-up and top-down skills because learners need both if they are to become proficient L2 writers. Many prominent researchers, such as Cope and Kalantzis (1993, 2000) and Johns (1997), have pointed out that learners can achieve social access and inclusion through a facility with language and writing. Achieving proficiency in writing requires explicit pedagogy in grammar and lexis and is important because one's linguistic repertoire and writing skills often determine one's social, economic, and political choices. Such experts in L2 teaching as Celce-Murcia (2001), Christie (1998), and Martin (1992) have similarly argued that a lack of instruction in L2 grammar and lexis disadvantages L2 learners in their vocational, academic, and professional careers and ultimately reduces their options. These researchers have continued to emphasize the importance of language quality in L.2 writing because grammar and lexis are inextricable from meaning in written discourse and because L2 writers are ultimately evaluated based on their control of language and text construction in their written discourse.

To address the shortfalls of the writing pedagogy widely adopted in the 1980s, the practice of L2 writing instruction has begun to take a more balanced view of learning to write in an L2 (Silva \& Brice, 2004). For instance, Frodesen (2001) states that "the wholesale adoption of L.1 composition theories and practices for L2 writing classes seems misguided in light of the many differences between first and second language writers, processes, and products" (p. 234). ${ }^{2}$ According to Frodesen, the neglect of language instruction for L2 writers is most prevalent in the United States, where many continue to believe that comprehensible input is sufficient for language acquisition. Frodesen and other experts, such as Birch (2005), Byrd (2005), Byrd and Reid (1998), and Mckay (1993) point out that curriculum design in L2 writing instruction has to include grammar and vocabulary to enable L2 writers to communicate meaningfully and appropriately. With this objective in mind, prominent current positions advocate the integration of grammar and vocabulary curricula with L2 writing instruction.

\footnotetext{
${ }^{2}$ In the teaching of rhetoric and writing, the process/product debate originated in the late 19 th and early 20th century, when English departments were formally separated from, for example, philosophy departments in many U.K. and U.S. universities. These debates have continued unabated for more than a century now, but in the 1970 s and 1980 s, they aided in the institutionalization of composition studies in the United States-but not in other countries.
} 
New insights into the properties of written and spoken texts, combined with the growing recognition that L2 writing requires a substantial range of grammar and lexical skills, have led to considerable modifications in L2 writing instruction. At present, the grammatical and lexical features needed to construct formal academic writing and discourse are discussed and foregrounded (often under the umbrella term academic literacy) in many teacher education textbooks, such as those by Adger, Snow, and Christian (2002), Birch (2005), Brown (2001), Byrd and Reid (1998), Carter and Nunan (2001), Celce-Murcia (2001), Celce-Murcia and Olshtain (2000), Ferris and Hedgcock (2005), Hinkel (2004), Liu and Master (2003), and Weaver (1996).

\section{Teaching Writing to Young Learners}

Along these lines, the current approaches for teaching L2 writing to school-age children are similarly based on the premise that learners need to attain fundamental proficiency in spelling and in letter and word recognition, followed by a focus on the syntactic parsing of morphemes, phrases, and sentences (e.g., Celce-Murcia \& Olshtain, 2000). During the subsequent stages of learners' writing development, more complex tasks are introduced to include emotive (or personal) writing, for example, narratives that tell about personal experiences, letters to friends, and diaries. Then instruction begins to advance to school-based writing, usually integrated with reading as well as with grammar and vocabulary learning (Adger, Snow, \& Christian, 2002; Birch, 2005; Schleppegrell, 2004).

\section{Integrated and Content-Based Teaching of Writing}

Much of the current integrated instruction in L2 writing, grammar, and vocabulary takes place in conjunction with reading, content-based, and form-focused instruction to improve the overall quality of L2 prose (e.g., Cope, \& Kalantzis, 1993; Hedgcock, 2005; Williams, 2005). For example, to promote learners' noticing of how particular grammar and lexis are employed in authentic written text and discourse, teachers can select readings from a wide array of genres, such as narrative, exposition, or argumentation. Based on reading content, practice in text analysis can become a useful springboard for an instructional focus on the specific uses of grammar structures and contextualized vocabulary. Similarly, instruction can address the features of written register by bringing learners' attention to the situational variables of language in context, such as e-mail messages, news reports, or written academic prose, and their attendant linguistic and discourse features (Celce- 
Murcia \& Olshtain, 2000; Hinkel, 2002, 2003, 2004; Larsen-Freeman, 2002; Nattinger \& DeCarrico, 1992).

Another integrated approach to teaching writing together with reading is rooted in the foundations of the systemic functional linguistics and genre theory that examines the uses of language in texts written for particular, mostly academic and specific, purposes. Genre-based instruction seeks to enable L2 learners to analyze academic discourse while reading and to produce academic writing that adheres to the sociocultural norms of a particular academic (or professional) genre (e.g., Christie, 1998; Cope \& Kalantzis, 1993, 2000; Martin, 1992). However, use of a genre-centered approach in educational contexts has not been without controversy. Many experts believe that genres and their linguistic features may be subjective, vaguely defined, unstable, or even irrelevant to diverse types of ESL/EFL learners (for detailed discussion, see, e.g., Silva \& Brice, 2004; Widdowson, 2003).

\section{A FINAL WORD}

In part due to its comparatively short history as a discipline, TESOL continues to be a dynamic field, one in which new venues and perspectives are still unfolding. In the past two decades or so, to a great extent, the innovations in the teaching of L2 skills have been driven by (a) new knowledge about the learner and the English language, (b) a greater balance in the teaching of both bottom-up and top-down L2 skills, and (c) a proliferation of integrated instructional models. The purposes for which people learn English today have also evolved from a cultural and educational enterprise to that of international communication. The growth of new knowledge about the how and the what of L2 teaching and learning are certain to continue and will probably remain as hallmarks of TESOL's disciplinary maturation.

\section{ACKNOWLEDGMENTS}

For their insightful and helpful comments on early drafts of this article, I express my sincere gratitude to Marianne Celce-Murcia, University of California, Los Angeles, Sandra McKay, State University of San Francisco, Sandra Fotos, Senshu University, and Ken Benoit, Seattle University, whose suggestions for revisions were instrumental in fine-tuning the final version. Additionally, Suresh Canagarajah and two anonymous reviewers provided very useful feedback and comments that helped develop the final version. 


\section{THE AUTHOR}

Eli Hinkel has taught ESL and applied linguistics, as well as trained teachers, for more than 20 years and has published numerous books and articles on learning second culture, and second language grammar, writing, and pragmatics. She is also the editor of Lawrence Erlbaum's ESL and Applied Linguistics Professional Series.

\section{REFERENCES}

Adger, C., Snow, C., \& Christian, D. (2002). What teachers need to know about language. McHenry, IL: Center for Applied Linguistics.

Aston, G. (1995). Corpora in language pedagogy: Matching theory and practice. In G. Cook and B. Seidlhofer (Ed.), Principles and practice in applied linguistics (pp. 257-270). Oxford: Oxford University Press.

Bialystok, E. (2002). Cognitive processes of L2 user. In V. J. Cook (Ed.), Portraits of the L2 user (pp. 145-165). Clevedon, England: Multilingual Matters.

Birch, B. (2002). English L2 reading: Getting to the bottom. Mahwah, NJ: Lawrence Erlbaum.

Birch, B. (2005). Learning and teaching English grammar, K-12. White Plains, NY: Prentice Hall.

Breen, M. (Ed.). (2001). Learner contributions to language learning: New directions in research. Harlow, England: Pearson.

Breen, M., \& Littlejohn, A. (Eds.). (2000). Classroom decision-making. Cambridge: Cambridge University Press.

Brown, H. D. (2001). Teaching by principles (2nd ed.). White Plains, NY: Pearson.

Byrd, P. (2005). Instructed grammar. In E. Hinkel (Ed.), Handbook of research in second language leaching and leaming (pp. 545-562). Mahwah, NJ: Lawrence Erlbaum.

Byrd, P., \& Reid, J. (1998). Crammar in the composition classroom. Boston: Heinle \& Heinle.

Canagarajah, S. (2002). Globalization, methods, and practice in periphery classrooms. In D. Block \& D. Cameron (Eds.), Globalization and language leaching (pp. 134-150). London: Routledge.

Canagarajah, S. (Ed.). (2005). Reclaiming the local in language policy and practice. Mahwah, NJ: Lawrence Erlbaum.

Carter, R., \& Nunan, D. (Eds.). (2001). The Cambridge guide to leaching English to speakers of other languages. Cambridge: Cambridge University Press.

Celce-Murcia, M. (1995). Discourse analysis and the teaching of listening. In G. Cook $\&$ B. Seidlhofer (Eds.), Principle and practice in applied linguisics: Studies in honor of H. G. Widdowson (pp. 363-377). Oxford: Oxford University Press.

Celce-Murcia, M. (Ed.). (2001). Teaching English as a second or foreign language (3rd ed.). Boston: Heinle \& Heinle.

Celce-Murcia, M., \& Olshtain, E. (2000). Discourse and context in language teaching. New York: Cambridge University Press.

Chikamatsu, N. (1996). The effects of L1 orthography on L2 word recognition. Studies in Second Language Acquisition, 18, 403-432.

Christie, F. (1998). Learning the literacies of primary and secondary schooling. In F. Christie \& R. Misson (Eds.), Lileracy and schooling: New directions (pp. 47-73). London: Routledge.

Chun, D. (2002). Discourse intonation in L2. Amsterdam: John Benjamins.

Coady, J. (1997). L2 vocabulary acquisition through extensive reading. In J. Coady \& T. Huckin (Eds.), Second language vocabulary acquisition (pp. 225-237). Cambridge: Cambridge University Press. 
Coady, J., \& Huckin, T. (1997). Second language vocabulary acquisilion: A rationale for pedagogy. Cambridge: Cambridge University Press.

Conrad, S. (2000). Will corpus linguistics revolutionize grammar teaching in the 21 st century? TESOL Quarlerly, 34, 548-560.

Conrad, S. (2005). Corpus linguistics and L2 teaching. In E. Hinkel (Ed.), Handbook of research in second language teaching and learning (pp. 393-410). Mahwah, NJ: Lawrence Erlbaum.

Cook, G. (1997). Language play, language learning. ELT Journal, 51, 224-231.

Cook, G. (1998). The uses of reality: A reply to Ronald Carter. ELT Journal, 52, 57-63.

Cope, B., \& Kalantzis, M. (Eds.). (1993). The powers of literacy: A genre approach to teaching writing. Pittsburgh, PA: University of Pittsburgh Press.

Cope, B., \& Kalantzis, M. (Eds.). (2000). Multiliteracies: Literacy learning and the design of social futures. New York: Routledge.

Ediger, A. (2001). Teaching children literacy skills in a second language. In M. CelceMurcia (Ed.), Teaching English as a second or foreign language (3rd ed., pp. 153-169). Boston: Heinle \& Heinle.

Ellis, R. (2003). Task-based language learning and teaching: Oxford: Oxford University Press.

Eskey, D. (1988). Holding in the bottom: An interactive approach to the language problems of second language readers. In P. Carrell, J. Devine, \& D. Eskey (Eds.), Interactive approaches to second language reading (pp. 93-100). Cambridge: Cambridge University Press.

Eskey, D. (2005). Reading in a second language. In E. Hinkel (Ed.), Handbook of research on second language teaching and learning (pp. 563-580). Mahwah, NJ: Lawrence Erlbaum.

Ferris, D., \& Hedgcock, J. (2005). Teaching ESL composition (2nd ed.). Mahwah, NJ: Lawrence Erlbaum.

Fotos, S. (2001). Cognitive approaches to grammar instruction. In M. Celce-Murcia (Ed.), Teaching English as a second or foreign language (3rd ed., pp. 267-284). Boston: Heinle \& Heinle.

Fotos, S. (2002). Structure-based interactive tasks for the EFL grammar learner. In E. Hinkel \& S. Fotos (Eds.), New perspectives on grammar teaching in second language classrooms (pp. 135-154). Mahwah, NJ: Lawrence Erlbaum.

Frodesen, J. (2001). Grammar in writing. In M. Celce-Murcia (Ed.), Teaching English as a second or foreign language (3rd ed., pp. 233-248). Boston: Heinle \& Heinle.

Hazenberg, S., \& Hulstijn, J. (1996). Defining a minimal receptive second language vocabulary for non-native university students: An empirical investigation. Applied Linguistics, 17, 145-163.

Hedgcock, J. (2005). Taking stock of research and pedagogy in L2 writing. In E. Hinkel (Ed.), Handbook of research in second language teaching and learning (pp. 597-614). Mahwah, NJ: Lawrence Erlbaum.

Hinkel, E. (2001). Building awareness and practical skills for cross-cultural communication in ESL/EFL. In M. Celce-Murcia (Ed.), Teaching English as a second or foreign. language (3rd ed., pp. 443-458). Boston: Heinle \& Heinle.

Hinkel, E. (2002). Second language writers' texl. Mahwah, NJ: Lawrence Erlbaum.

Hinkel, E. (2003). Simplicity without elegance: Features of sentences in L2 and L1 academic texts. TESOL Quarterly, 37, 275-301.

Hinkel, E. (2004). Teaching academic ESL woriting: Practical techniques in vocabulary and grammar. Mahwah, NJ: Lawrence Erlbaum.

Hu, M., \& Nation, P. (2000). Unknown vocabulary density and reading comprehension. Reading in a Foreign Language, 13, 403-430.

Hulstijn, J. (2001). Intentional and incidental second language vocabulary learning: 
A reappraisal of elaboration, rehearsal and automaticity. In P. Robinson (Ed.), Cognition and second language instruction (pp. 258-287). Cambridge: Cambridge University Press.

Jenkins, J. (2000). The phonology of English as an international language. Oxford: Oxford University Press.

Johns, A. (1997). Text, role, and context: Developing academic literacies. Cambridge: Cambridge University Press.

Kasper, G. (2001). Four perspectives on pragmatic development. Applied Linguistics, $22,502-530$.

Kasper, G., \& Roever, C. (2005). Pragmatics in second language learning. In $\mathrm{E}$. Hinkel (Ed.), Handbook of research on second language teaching and leaming (pp. 317-334). Mahwah, NJ: Lawrence Erlbaum.

Koda, K. (1999). Development of L2 intraword orthographic sensitivity and decoding skills. Modern Language Joumal, 83, 51-64.

Koda, K. (2005). Insights into second language reading. New York: Cambridge University Press.

Kumaravadivelu, B. (2003). Beyond methods: Macrostrategies for language teaching. New Haven, CT: Yale University Press.

Kumaravadivelu, B. (2005). Undersianding language teaching: From method to postmethod. Mahwah, NJ: Lawrence Erlbaum.

Larsen-Freeman, D. (2000). Techniques and principles in language teaching (2nd ed.). Oxford: Oxford University Press.

Larsen-Freeman, D. (2002). The grammar of choice. In E. Hinkel \& S. Fotos (Eds.), New perspectives on grammar teaching in second and foreign language classrooms (pp. 103-118). Mahwah, NJ: Lawrence Erlbaum.

Lazaraton, A. (2001). Teaching oral skills. In M. Celce-Murcia (Ed.), Teaching English as a second or forcign language (3rd ed., pp. 103-115). Boston: Heinle \& Heinle.

Lightbown, P. (2000). Classroom SLA research and second language teaching. Applied Linguistics, 21, 431-462.

Lightbown, P., \& Spada, N. (1990). Focus-on-form and corrective feedback in communicative language teaching; Effects on second language learning. Studies in Second Language Acquisition, 12, 429-448.

Liu, D., \& Master, P. (2003). Grammar teaching in teacher education. Alexandria, VA: TESOL.

Martin, J. (1992). English text: System and structure. Philadelphia: Benjamins.

Master, P. (2005). Research in English for specific purposes. In E. Hinkel (Ed.), Handbook of research in second language teaching and learning (pp. 99-116). Mahwah, NJ: Lawrence Erlbaum.

McCarthy, M., \& O'Keeffe, A. (2004). Research in the teaching of speaking. Annual Review of Applied Linguistics, 24, 26-43.

McKay, S. (1993). Agendas for second language literacy. New York: Cambridge University Press.

McKay, S. (2002). Teaching English as an international language. Oxford: Oxford University Press.

Mckay, S., \& Wong, S. L. C. (1996). Multiple discourses, multiple identities: Investment and agency in second-language learning among Chinese adolescent immigrant students. Harvard Educational Review, 66, 577-608.

Mendelsohn, D. J. (1994). Leaming to listen: A strategy-based approach for the secondlanguage leamer. San Diego: Dominie Press.

Nation, I. S. P. (1990). Teaching and learning vocabulary. New York: Newbury House.

Nation, I. S. P. (2001). Leaming vocabulary in another language. Cambridge: Cambridge University Press. 
Nation, I. S. P. (2005). Teaching and learning vocabulary. In E. Hinkel (Ed.), Handbook of research on second language leaching and learning (pp. 581-596). Mahwah, NJ: Lawrence Erlbaum.

Nattinger, J., \& DeCarrico, J. (1992). Lexical phrases and language teaching. Oxford: Oxford University Press.

Nunan, D. (1999). Second langrage leaching and learning. Boston: Heinle \& Heinle.

Nunan, D. (Ed.). (2003). Practical English language teaching. New York: McGraw-Hill.

Paran, A. (1996). Reading in EFL: Facts and fictions. English Language Teaching Journal, 50, 25-34.

Richards, J. C. (2005, March). How research informs and influences teaching materials. Paper presented at the 39th Annual TESOL. Convention and Exhibit, San Antonio, TX.

Richards, J., \& Rodgers, T. (2001). Approaches and methods in language teaching (2nd ed.). Cambridge: Cambridge University Press.

Rost, M. (2001). Teaching and researching listening. London: Longman.

Rost, M. (2005). L2 listening. In E. Hinkel (Ed.), Handbook of research on second language teaching and learning (pp. 503-528). Mahwah, NJ: Lawrence Erlbaum.

Rost, M., \& Ross, S. (1991). Learner use of strategies in interaction: Typology and teachability. Language Learning, 41, 235-273.

Schleppegrell, M. (2004). The language of schooling. Mahwah, NJ: Lawrence Erlbaum.

Schmidt, R. (1993). Awareness and second language acquisition. Annual Review of Applied Linguistics, 13, 206-226.

Seedhouse, P. (1999). Task-based interaction. ELT Journal, 53, 149-156.

Shimron, J., \& Savon, T. (1994). Reading proficiency and orthography: Evidence from Hebrew. Language Learming, 44, 5-27.

Silva, T. (1993). Toward an understanding of the distinct nature of L2 writing: The ESL research and its implications. TESOL Quarterly, 27, 657-677.

Silva, T., \& Brice, C. (2004), Research in teaching writing. Annual Review of Applied Linguistics, 24, 70-106.

Snow, M. A. (2005). A model of academic literacy for integrated language and content instruction. In E. Hinkel (Ed.), Handbook of research in second language leaching and learning (pp. 693-712). Mahwah, NJ: Lawrence Erlbaum.

Swain, M. (1991). Manipulating and complementing content teaching to maximize second language learning. In E. Kellerman, R. Phillipson, L. Selinker, M. Sharwood Smith, \& M. Swain (Eds.), Foreign/second language pedagogical research (pp. 234-50). Clevedon, England: Multilingual Matters.

Swan, M. (2005). Legislation by hypothesis: The case of task-based instruction. Applied Linguistics, 26, 376-401.

Tarone, E. (2005). Speaking in a second language. In E. Hinkel (Ed.), Handbook of research in second language leaching and leaming (pp. 485-502). Mahwah, NJ: Lawrence Erlbaum.

Tsui, A. B., \& Fullilove, J. (1998). Bottom-up or top-down processing as a discriminator of L2 listening performance. Applied Linguistics, 19, 432-451.

Ur, P. (1996). A course in language teaching: Practice and theory. Cambridge: Cambridge University Press.

Vandergrift, L. (1999). Facilitating second language listening comprehension: Acquiring successful strategies. English Language Teaching Joumal, 53, 168-176.

Vandergrift, L. (2004). Listening to learn or learning to listen? Annual Reviow of Applied Linguistics, 24, 3-25.

Wallace, C. (1992). Reading. Oxford: Oxford University Press.

Wallace, C. (2001). Reading. In R. Carter \& D. Nunan (Eds.), The Cambridge guide to 
teaching English to speakers of other languages (pp. 21-28). Cambridge: Cambridge University Press.

Weaver, C. (1996). Teaching grammar in context. Portsmouth, NH: Boynton/Cook.

Widdowson, H. (1990). Aspects of language teaching. Oxford: Oxford University Press.

Widdowson, H. (1993). Perspectives on communicative language teaching: Syllabus design and methodology. In J. Alatis (Ed.), Georgetown University Round Table on Language and Linguistics 1992: Language, communication, and social meaning (pp. 501-507). Washington, DC: Georgetown University Press.

Widdowson, H. (2000). On the limitations of linguistics applied. Applied Linguistics, $21,3-25$.

Widdowson, H. (2003). Defining issues in English language teaching. Oxford: Oxford University Press.

Williams, J. (2005). Teaching writing in second and foreign language classrooms. Boston: McGraw-Hill.

Yule, G., \& Tarone, E. (1997). Investigating L2 reference: Pros and cons. In G. Kasper \& E. Kellerman (Eds.), Advances in communication strategy research (pp. 17-30). New York: Longman. 